\title{
Author Correction: High-throughput and high- efficiency sample preparation for single-cell proteomics using a nested nanowell chip
}

Jongmin Woo (D), Sarah M. Williams, Lye Meng Markillie (1D, Song Feng (D), Chia-Feng Tsai, Victor Aguilera-

Vazquez, Ryan L. Sontag, Ronald J. Moore (D), Dehong Hu (D), Hardeep S. Mehta, Joshua Cantlon-Bruce, Tao Liu (D), Joshua N. Adkins (1), Richard D. Smith (1), Geremy C. Clair (1), Ljiljana Pasa-Tolic (1) \& Ying Zhu (1)

Correction to: Nature Communications https://doi.org/10.1038/s41467-021-26514-2, published online 29 October 2021.

In this article the author name Chia-Feng Tsai was incorrectly written as Chai-Feng Tsai.

The grant number U01 HL148860 relating to NIH grants for Joshua N. Adkins and Geremy C. Clair was omitted. The original article has been corrected.

Published online: 30 November 2021

\footnotetext{
(c) Open Access This article is licensed under a Creative Commons Attribution 4.0 International License, which permits use, sharing, adaptation, distribution and reproduction in any medium or format, as long as you give appropriate credit to the original author(s) and the source, provide a link to the Creative Commons license, and indicate if changes were made. The images or other third party material in this article are included in the article's Creative Commons license, unless indicated otherwise in a credit line to the material. If material is not included in the article's Creative Commons license and your intended use is not permitted by statutory regulation or exceeds the permitted use, you will need to obtain permission directly from the copyright holder. To view a copy of this license, visit http://creativecommons.org/licenses/by/4.0/.
}

This is a U.S. Government work and not under copyright protection in the US; foreign copyright protection may apply 2021 